Research article

\title{
Monoamine related functional gene variants and relationships to monoamine metabolite concentrations in CSF of healthy
} volunteers

\author{
Erik G Jönsson*1, Jessica Bah², Jonas Melke2, Rami Abou Jamra3, \\ Johannes Schumacher ${ }^{3}$, Lars Westberg ${ }^{2}$, Roland Ivo ${ }^{3}$, Sven Cichon ${ }^{4}$, \\ Peter Propping 3 , Markus M Nöthen ${ }^{4}$, Elias Eriksson ${ }^{2}$ and Göran C Sedvall ${ }^{1}$
}

Address: ${ }^{1}$ Department of Clinical Neuroscience, Psychiatry Section, HUBIN project, Karolinska Institutet, Stockholm, Sweden, ${ }^{2}$ Department of Pharmacology, Göteborg University, Sweden, ${ }^{3}$ Institute of Human Genetics, University of Bonn, Germany and ${ }^{4}$ Department of Medical Genetics, University of Antwerp, Belgium

Email: Erik G Jönsson* - erikj@ks.se; Jessica Bah - jessica.bah@pharm.gu.se; Jonas Melke - jonas.melke@pharm.gu.se; Rami Abou Jamra - rami.aboujamra@uni-bonn.de; Johannes Schumacher - johannes.schumacher@uni-bonn.de;

Lars Westberg - lars.westberg@pharm.gu.se; Roland Ivo - Roland.Ivo@gmx.de; Sven Cichon - Sven.Cichon@uia.ua.ac.be;

Peter Propping - propping@uni-bonn.de; Markus M Nöthen - mnoethen@uia.ua.ac.be; Elias Eriksson - elias.eriksson@pharm.gu.se;

Göran C Sedvall - goran.sedvall@ks.se

* Corresponding author

Published: 04 March 2004

BMC Psychiatry 2004, 4:4

This article is available from: http://www.biomedcentral.com/I47I-244X/4/4

(C) 2004 Jönsson et al; licensee BioMed Central Ltd. This is an Open Access article: verbatim copying and redistribution of this article are permitted in all media for any purpose, provided this notice is preserved along with the article's original URL.
Received: 19 September 2003

Accepted: 04 March 2004

\begin{abstract}
Background: Concentrations of monoamine metabolites in human cerebrospinal fluid (CSF) have been used extensively as indirect estimates of monoamine turnover in the brain. CSF monoamine metabolite concentrations are partly determined by genetic influences.

Methods: We investigated possible relationships between DNA polymorphisms in the serotonin $2 \mathrm{C}$ receptor $(H T R 2 C)$, the serotonin $3 A$ receptor $(H T R 3 A)$, the dopamine $D_{4}$ receptor (DRD4), and the dopamine $\beta$-hydroxylase $(D B H)$ genes and CSF concentrations of 5 -hydroxyindolacetic acid (5HIAA), homovanillic acid (HVA), and 3-methoxy-4-hydroxyphenylglycol (MHPG) in healthy volunteers $(\mathrm{n}=90)$.

Results: The HTR3A I78 C/T variant was associated with 5-HIAA levels $(p=0.02)$. The $D B H-I 02 I$ heterozygote genotype was associated with 5-HIAA $(p=0.0005)$ and HVA $(p=0.009)$ concentrations. Neither the HTR2C Cys23Ser variant, nor the DRD4 -52I C/T variant were significantly associated with any of the monoamine metabolites.
\end{abstract}

Conclusions: The present results suggest that the HTR3A and DBH genes may participate in the regulation of dopamine and serotonin turnover rates in the central nervous system.

\section{Background}

Concentrations of the major serotonin metabolite 5- hydroxyindoleacetic acid (5-HIAA), the major dopamine metabolite homovanillic acid (HVA), and the major 
norepinephrine metabolite 3-methoxy-4-hydroxyphenylglycol (MHPG) in lumbar cerebrospinal fluid (CSF) have been used extensively as indirect measures of monoamine turnover in the brain of humans. Studies of human twins indicate that CSF 5-HIAA and HVA levels are under familial influence of both genetic and environmental origin, whereas MHPG is under major genetic influence [1]. In rhesus monkeys significant portions of CSF 5HIAA, HVA, and MHPG in the central nervous system, have been shown to be determined by genetic mechanisms [2].

A number of serotonin receptors mediate the effects of serotonin. Among several functions, the serotonin receptor $5-\mathrm{HT}_{2 \mathrm{C}}$, which is densely expressed throughout the brain [3], seems to be directly involved in the regulation of serotonin and norepinephrine activities in the brain [46]. The $5-\mathrm{HT}_{2 \mathrm{C}}$ gene (HTR2C) is localised to chromosome Xq24 [7]. An HTR2C variant giving rise to a Cystein to Serine substitution at position 23 of the protein has been identified [8]. This variant was shown to influence the CSF MHPG concentration in a Finnish sample of predominantly alcoholic offenders [9].

In contrast to all other serotonin receptors, which are $\mathrm{G}$ protein-coupled, the 5- $\mathrm{HT}_{3}$ receptor is a ligand-gated ion channel [10]. In the brain $5-\mathrm{HT}_{3}$ receptors are localised in areas including the amygdala, hippocampus, and caudate nucleus. In addition to their effects on serotonin-regulated physiological processes, there are data suggesting that $5-\mathrm{HT}_{3}$ receptors influence the activity of several other neurotransmitters, including norepinephrine and dopamine [11-13]. The $5-\mathrm{HT}_{3 \mathrm{~A}}$ gene (HTR3A) is localised to chromosome 11q23.1-q23.2 [10]. An HTR3A single nucleotide polymorphism $(178 \mathrm{C} / \mathrm{T})$ in the upstream regulatory region was recently discovered to be of putative functional importance, because luciferase reporter assays in human embryonal kidney cells showed a two to three times higher activity of the rare allele compared to the wildtype [14]. This HTR3A variant was reported to be associated with bipolar disorder [14] and the personality trait harm avoidance in women [15].

The dopamine $\mathrm{D}_{4}$ receptor has a predominantly cortical localisation in the human brain [16]. Among several effects, the dopamine $\mathrm{D}_{4}$ receptor seems to modulate dopamine synthesis and turnover $[17,18]$. The dopamine $\mathrm{D}_{4}$ receptor gene (DRD4) is located to chromosome 11 15.5 [19]. Recently, a putative functional DRD4 upstream region variant $(-521 \mathrm{C} / \mathrm{T})$ was discovered, where the $-521 \mathrm{C}$ allele was reported to be $40 \%$ less active than $521 \mathrm{~T}$ allele in a chloramphenicol acetyltransferase assay using human retinoblastoma cells [20]. This DRD4 variant was associated with schizophrenia [20] as well as the personality trait novelty seeking in some [21-24] but not all studies [25-31]. However, meta-analyses suggested association with both conditions [32-34].

The enzyme dopamine $\beta$-hydroxylase (D $\beta H$ ) catalyses the conversion of dopamine to norepinephrine. $\mathrm{D} \beta \mathrm{H}$ is localised in catecholamine-containing vesicles of noradrenergic and adrenergic cells [35,36]. D $\beta \mathrm{H}$ enzyme activity has been shown to be heritable to a great extent $[1,37]$. The $\mathrm{D} \beta \mathrm{H}$ gene $(D B H)$ is located on chromosome 9q34 [38]. Recently, a DBH promoter variant (-1021 C/T) was shown to strongly influence plasma D $\beta \mathrm{H}$-activity [39-41], indicating a functional effect. In the present study we have examined the HTR2C Cys23Ser, HTR3A $178 \mathrm{C} / \mathrm{T}$, DRD4 $521 \mathrm{C} / \mathrm{T}$ and $\mathrm{DBH}-1021 \mathrm{C} / \mathrm{T}$ variants for possible relationships to concentrations of 5-HIAA, HVA, and MHPG in lumbar CSF from healthy Swedish volunteers.

\section{Methods \\ Healthy human volunteers}

The study was approved by the Ethics Committee of the Karolinska Hospital, Stockholm. Informed consent of the subjects was obtained after the nature of the procedures had been fully explained.

The characteristics and assessment of the subjects participating in the present study have been described previously $[42,43]$. Caucasian individuals $(n=90)$ were recruited predominantly among students or hospital staff. Lumbar puncture (LP) was performed in all subjects. Height was also recorded. Back length, defined as the distance between the external occipital protuberance and the insertion point of the lumbar needle with the subject in the lying position, was measured in 63 subjects. Eight to 19 years later a structured interview was performed by a psychiatrist (EJ) to assess psychiatric morbidity (DSM-III-R; [44]), somatic illness and presence of mental and nervous system disorders among relatives. Subjects completed a questionnaire regarding smoking habits. Hospital records were obtained and examined for diagnosis. Genealogical data for antecedents up to the third degree were obtained from parish registers to assess the origin of the individuals. Subjects who reported any lifetime psychiatric disorder were excluded.

Of the 90 subjects 52 were men and 38 women. The age range at the time of the structured interview was 29 to 56 , with a mean \pm standard deviation of $40.5 \pm 6.4$ years. The mean age \pm standard deviation at LP was $27.4 \pm 5.9$ years, age range $18-43$. Thirty-six were university graduates. Twenty-one subjects had a family history of major mental illness defined as at least one first or second degree relative with schizophrenia, schizoaffective disorder, bipolar disorder, recurrent unipolar disorder, other non-organic psychosis, or who had committed suicide. Of the subjects 54 were or had been regular tobacco users, 25 were non- 
smokers or had only used tobacco once or a few times in their life, while data were missing for 11 individuals. Of the women, 15 used oral contraceptives at LP, 21 did not, while data were missing for two individuals. Except for oral contraceptives all participants were drug free at LP. Genealogical data implicated that $89.6 \%$ and $4.7 \%$ of the genes originated in ancestors born in Sweden and Finland, respectively, and the remaining $5.7 \%$ were distributed on 8 European countries.

\section{CSF monoamine metabolite concentrations}

All subjects had at least $8 \mathrm{~h}$ of bed-rest in the hospital, abstaining from food and smoking. CSF samples were obtained by LP between 8 and 9 a.m. with the subjects in the sitting $(\mathrm{n}=41)$ or recumbent $(\mathrm{n}=47)$ position. Samples of $12.5 \mathrm{ml}$ CSF were drawn according to a standardised sampling procedure [45]. Samples were stored at below $-20^{\circ} \mathrm{C}$ and analysed within two months. 5-HIAA, HVA, and MHPG concentrations were measured by mass fragmentography with deuterium labelled internal standards [46].

\section{Genotype analyses}

Venous blood was taken from all individuals into EDTAcontaining tubes. DNA was isolated as previously described [47]. The HTR2C Cys23Ser variant was genotyped in accordance with Lappalainen et al [8]. The HTR3A $178 \mathrm{C} / \mathrm{T}, \mathrm{DRD} 4-521 \mathrm{C} / \mathrm{T}$, and DBH -1021 C/T variants were genotyped as previously described $[15,26,48]$.

\section{Data analyses}

One way analysis of variance (ANOVA) was used for comparisons between genotypes and 5-HIAA, HVA, and MHPG concentrations, respectively. To correct monoamine metabolite levels for back length and use of oral contraceptives (among women), suggestive but discussed confounding variables for monoamine metabolite concentrations in lumbar CSF $[42,43,49]$, analysis of covariance (ANCOVA) was used. For those subjects where back length was not available, estimated back length values, based on the relationship between back length and height, was used as previously described $[42,43]$. Significance level was defined as a p-value lower than 0.05. Power was estimated in accordance with published methods [50,51].

\section{Results}

\section{Relationships between HTR2C genotypes and CSF} monoamine metabolite concentrations

The HTR2C genotyping was successful in 86 individuals. Among men the allele frequencies were 0.88 (Cys23) and 0.12 (Ser23). In women the allele frequencies were 0.89 (Cys23) and 0.11 (Ser23), distributed on the following genotypes: Cys23Cys (81\%), Cys23Ser (16\%), and Ser23Ser (3\%). As the HTR2C gene is localised on the X chromosome, each gender was analysed separately. Among women, the Ser23Ser and Cys23Ser genotypes were pooled and analysed versus the Cys23Cys genotype, because of the small number of Ser23Ser subjects. There were no significant relationship between genotypes and any of the CSF monoamine metabolite concentrations neither among men or women (table 1).

\section{Relationships between HTR3A genotypes and CSF monoamine metabolite concentrations}

The HTR3A $178 \mathrm{C} / \mathrm{C}$ genotype was the most frequent (67\%), followed by the $178 \mathrm{C} / \mathrm{T}(30 \%)$ and the $178 \mathrm{~T} / \mathrm{T}$ (3\%) genotypes. The allele frequencies were 0.82 (178C) and 0.18 (178T). The $178 \mathrm{~T} / \mathrm{T}$ and $178 \mathrm{C} / \mathrm{T}$ genotypes were pooled in the calculations, because of the small number of subjects carrying the $178 \mathrm{~T} / \mathrm{T}$ genotype. In the total sample there were associations between the HTR3A variant and 5-HIAA ( $p=0.002)$ and HVA $(\mathrm{p}=0.006)$ concentrations, with higher concentrations of these monoamine metabolites in carriers of the T-containing genotypes (table 2). However, when corrected for backlength the association between the HTR3A variant and lumbar HVA concentrations was reduced to a trend $(\mathrm{p}=$ 0.08 ). In the male sub-sample, no significant relationships between HTR3A variation and 5-HIAA or HVA concentrations emerged. Among women the relationship between HTR3A variation and 5-HIAA concentrations, indicating higher 5-HIAA levels in subjects carrying the $178 \mathrm{~T}$ allele, was significant both uncorrected $(p=0.004)$, corrected for back-length $(\mathrm{p}=0.006)$, and corrected for use of oral contraceptives ( $\mathrm{p}=0.03$; table 2$)$. However, in the female sub-sample the association between HTR3A and HVA concentrations was of borderline significance $(\mathrm{p}$ $=0.05$ uncorrected, $\mathrm{p}=0.03$ corrected for use of oral contraceptives), but was non-significant after correction for back-length ( $p=0.12)$. Inspection of the CSF levels of the different genotype groups indicated a possible heterosis effect with regard to the CSF 5-HIAA and HVA concentrations [52]. We therefore also performed calculations pooling the homozygotic genotypes. However, the probability levels of significance did not exceed those obtained pooling the $\mathrm{T} / \mathrm{T}$ and $\mathrm{C} / \mathrm{T}$ genotypes (table 2 ). There were no significant relationships between the HTR3A genotype and MHPG concentrations (table 2).

\section{Relationships between DRD4 genotypes and CSF monoamine metabolite concentrations}

The DRD4 -521 C/T genotype was the most frequent (58\%), followed by the $-521 \mathrm{~T} / \mathrm{T}(28 \%)$ and the $-521 \mathrm{C} / \mathrm{C}$ genotypes $(14 \%)$. The allele frequencies were 0.57 ($521 \mathrm{~T})$ and $0.43(-521 \mathrm{C})$. When women were analysed separately, the $-521 \mathrm{C} / \mathrm{C}$ and $-521 \mathrm{C} / \mathrm{T}$ genotypes were pooled, because of the small number of $-521 \mathrm{C} / \mathrm{C}$ subjects. There was no significant relationship between $D R D 4$ genotypes and any of the CSF monoamine metabolite 
Table I: Serotonin receptor $5-\mathrm{HT}_{2 \mathrm{C}}($ HTR2C) genotypes and relationships to monoamine metabolite concentrations in human lumbar cerebrospinal fluid.

\begin{tabular}{|c|c|c|c|c|c|c|c|c|c|c|c|}
\hline \multirow[b]{2}{*}{$\begin{array}{l}\text { HTR2C Allele/ } \\
\text { genotype }\end{array}$} & \multirow[b]{2}{*}{ Sex } & \multirow[b]{2}{*}{$\mathrm{n}$} & \multicolumn{3}{|c|}{ 5-HIAA } & \multicolumn{3}{|c|}{ HVA } & \multicolumn{3}{|c|}{ MHPG } \\
\hline & & & $\begin{array}{c}\text { Mean } \pm \text { SD } \\
(\mathrm{nmol} / \mathrm{L})\end{array}$ & $\mathrm{F}^{\mathrm{a}} \mathrm{P}^{\mathrm{a}}$ & $\mathrm{F}^{\mathrm{b}} \mathrm{p}^{\mathrm{b}}$ & $\begin{array}{c}\text { Mean } \pm \text { SD } \\
(\mathrm{nmol} / \mathrm{L})\end{array}$ & $\mathrm{F}^{\mathrm{a}} \mathrm{P}^{\mathrm{a}}$ & $\mathrm{F}^{\mathrm{b}} \mathrm{p}^{\mathrm{b}}$ & $\begin{array}{c}\text { Mean } \pm \text { SD } \\
(\mathrm{nmol} / \mathrm{L})\end{array}$ & $F^{a} P^{a}$ & $\mathrm{Fb}^{\mathrm{b}} \mathrm{p}^{\mathrm{b}}$ \\
\hline Cys23 & Men & 43 & $92 \pm 40$ & $F=0.27$ & $F=0.13$ & $166 \pm 75$ & $F=0.73$ & $F=0.50$ & $43 \pm 8$ & $F=1.75$ & $F=1.48$ \\
\hline Ser23 & & 6 & $86 \pm 16$ & $p=0.61$ & $p=0.72$ & $144 \pm 39$ & $p=0.40$ & $p=0.48$ & $39 \pm 4$ & $p=0.19$ & $p=0.23$ \\
\hline Cys23Cys & Women & 30 & $105 \pm 39$ & $F=0.66$ & $F=0.57$ & $194 \pm 77$ & $F=2.14$ & $F=1.34$ & $40 \pm 6$ & $F=1.03$ & $F=0.91$ \\
\hline Cys23Serc & & 6 & $118 \pm 29$ & $P=0.42$ & $P=0.46^{d}$ & $231 \pm 69$ & $p=0.15$ & $\mathrm{p}=0.25^{\mathrm{e}}$ & $44 \pm 8$ & $P=0.32$ & $P=0.35^{f}$ \\
\hline Ser23Serc & & I & 107 & & & 229 & & & 38 & & \\
\hline
\end{tabular}

5-HIAA = 5-hydroxyindoleacetic acid; HVA = homovanillic acid; MHPG = 3-methoxy-4-hydroxyphenylglycol. Statistical comparisons done on monoamine metabolite residuals corrected a and uncorrected ${ }^{b}$ for back length. ${ }^{c} C y s 23$ Ser and Ser23Ser genotypes were combined in the analyses. $d$ Correction for use of oral contraceptives, $F=0.21, p=0.65$. e Correction for use of oral contraceptives, $F=0.84, p=0.37$. ${ }^{f}$ Correction for use of oral contraceptives, $F=0.22, p=0.64$.

Table 2: Serotonin receptor $5-\mathrm{HT}_{3 A}(H T R 3 A)$ genotypes and relationships to monoamine metabolite concentrations in human lumbar cerebrospinal fluid.

\begin{tabular}{|c|c|c|c|c|c|c|c|c|c|c|c|}
\hline \multirow[b]{2}{*}{$\begin{array}{c}\text { HTR3A } \\
\text { Genotype }\end{array}$} & \multirow[b]{2}{*}{ Sex } & \multirow[b]{2}{*}{$n$} & \multicolumn{3}{|c|}{ 5-HIAA } & \multicolumn{3}{|c|}{ HVA } & \multicolumn{3}{|c|}{ MHPG } \\
\hline & & & $\begin{array}{c}\text { Mean } \pm \text { SD } \\
(\mathrm{nmol} / \mathrm{L})\end{array}$ & $\mathrm{F}^{\mathrm{a}} \mathrm{P}^{\mathrm{a}}$ & $F^{b} p^{b}$ & $\begin{array}{c}\text { Mean } \pm \text { SD } \\
(\mathrm{nmol} / \mathrm{L})\end{array}$ & $F^{a} P^{a}$ & $F^{b} p^{b}$ & $\begin{array}{c}\text { Mean } \pm \text { SD } \\
(\mathrm{nmol} / \mathrm{L})\end{array}$ & $\mathrm{F}^{\mathrm{a}} \mathrm{P}^{\mathrm{a}}$ & $F^{b} p^{b}$ \\
\hline $\mathrm{T} / \mathrm{T}^{\mathrm{c}}$ & All & 3 & $105 \pm 52$ & $F=5.75$ & $F=10.22$ & $203 \pm 124$ & $F=3.25$ & $F=7.95$ & $44 \pm 5$ & $F=0.45$ & $F=0.29$ \\
\hline $\mathrm{C} / \mathrm{T}^{\mathrm{c}}$ & & 27 & $117 \pm 36$ & $p=0.02$ & $p=0.002$ & $211 \pm 67$ & $p=0.07$ & $p=0.006$ & $43 \pm 8$ & $p=0.50$ & $p=0.75$ \\
\hline $\mathrm{C} / \mathrm{C}$ & & 60 & $90 \pm 35$ & & & $166 \pm 7 \mid$ & & & $42 \pm 7$ & & \\
\hline $\mathrm{T} / \mathrm{T}^{\mathrm{c}}$ & Men & 1 & 52 & $F=0.31$ & $F=0.96$ & 113 & $F=0.75$ & $\mathrm{~F}=1.49$ & 49 & $F=0.20$ & $F=0.49$ \\
\hline $\mathrm{C} / \mathrm{T}^{\mathrm{c}}$ & & 11 & $106 \pm 33$ & $p=0.58$ & $p=0.33$ & $193 \pm 50$ & $p=0.39$ & $p=0.23$ & $44 \pm 9$ & $p=0.66$ & $p=0.49$ \\
\hline $\mathrm{C} / \mathrm{C}$ & & 40 & $90 \pm 37$ & & & $159 \pm 11$ & & & $43 \pm 7$ & & \\
\hline $\mathrm{T} / \mathrm{T}^{\mathrm{c}}$ & Women & 2 & $|3| \pm 34$ & $F=8.55$ & $F=9.75$ & $248 \pm 137$ & $F=2.49$ & $F=4.05$ & $41 \pm 3$ & $F=0.68$ & $F=1.00$ \\
\hline $\mathrm{C} / \mathrm{T}^{\mathrm{c}}$ & & 16 & $124 \pm 37$ & $p=0.006$ & $p=0.004^{d}$ & $224 \pm 76$ & $p=0.12$ & $p=0.05^{e}$ & $42 \pm 7$ & $p=0.42$ & $p=0.32^{f}$ \\
\hline $\mathrm{C} / \mathrm{C}$ & & 20 & $92 \pm 30$ & & & $179 \pm 64$ & & & $40 \pm 6$ & & \\
\hline
\end{tabular}

5-HIAA = 5-hydroxyindoleacetic acid; HVA = homovanillic acid; MHPG = 3-methoxy-4-hydroxyphenylglycol. Statistical comparisons done on monoamine metabolite residuals corrected and uncorrected ${ }^{b}$ for back length. ${ }^{\mathrm{c}} \mathrm{T} / \mathrm{T}$ and $\mathrm{C} / \mathrm{T}$ genotypes were combined in the analyses. ${ }^{\mathrm{d}} \mathrm{Correction}$ for use of oral contraceptives, $F=5.56, p=0.02$. e Correction for use of oral contraceptives, $F=1.76, p=0.19$. $f$ Correction for use of oral contraceptives, $F=0.17, p=0.68$. Analysing heterosis, i.e. comparing homo- vs heterozygotes: All subjects 5-HIAA: $F=10.03, p=0.002(F=5.71$, $p=0.02$ after correction for back length). All subjects HVA: $F=7.13, p=0.009(F=2.28, p=0.10)$. Men $5-H I A A: F=1.96, p=0.17(F=1.00, p=$ 0.32). Men HVA: 2.33, $p=0.13(F=1.40, p=0.24)$. Women 5 -HIAA: $F=6.73, p=0.01(F=5.65, p=0.02$ and $F=3.76, p=0.06$ corrected for back length and use of oral contraceptives, respectively). Women HVA: $F=2.49, p=0.12(F=1.03, p=0.32$ and $F=0.98, p=0.33$ corrected for back length and use of oral contraceptives, respectively).

concentrations neither in the total sample, nor among men or women (table 3).

\section{Relationships between DBH genotypes and CSF monoamine metabolite concentrations}

The DBH -1021 C/C genotype was the most frequent (71\%), followed by the $-1021 \mathrm{C} / \mathrm{T}(26 \%)$ and the -1021 $\mathrm{T} / \mathrm{T}$ genotypes $(3 \%)$. The allele frequencies were $0.84(-$ $1021 \mathrm{C})$ and $0.16(-1021 \mathrm{~T})$. The $-1021 \mathrm{~T} / \mathrm{T}$ and $-1021 \mathrm{C} / \mathrm{T}$ genotypes were pooled in the calculations, because of the small number of subjects with the $-1021 \mathrm{~T} / \mathrm{T}$ genotype. In the total sample there was an association between $D B H$ genotype and 5-HIAA concentrations ( $p=0.01$ uncorrected, $\mathrm{p}=0.003$ when corrected for back-length), with higher 5-HIAA levels in subjects with the -1021T containing genotypes (table 4). This relationship reached significance also among men $(\mathrm{p}=0.06$ uncorrected, $\mathrm{p}=$ 0.04 corrected for back length), but not among women (table 4). In the total sample there was a tendency for association $(\mathrm{p}=0.09)$ between the $D B H$ variant and HVA concentrations, with higher HVA levels in -1021T carriers (table 4). When corrected for back-length the strength of this difference was significant $(p=0.03)$. Neither in the 
Table 3: Dopamine $\mathrm{D}_{4}$ receptor (DRD4) genotypes and relationships to monoamine metabolite concentrations in human lumbar cerebrospinal fluid.

\begin{tabular}{|c|c|c|c|c|c|c|c|c|c|c|c|}
\hline \multirow[b]{2}{*}{$\begin{array}{c}\text { DRD4 } \\
\text { Genotype }\end{array}$} & \multirow[b]{2}{*}{ Sex } & \multirow[b]{2}{*}{$\mathrm{n}$} & \multicolumn{3}{|c|}{ 5-HIAA } & \multicolumn{3}{|c|}{ HVA } & \multicolumn{3}{|c|}{ MHPG } \\
\hline & & & $\begin{array}{c}\text { Mean } \pm \text { SD } \\
(\mathrm{nmol} / \mathrm{L})\end{array}$ & $\mathrm{Fa}^{\mathrm{a}} \mathrm{P}^{\mathrm{a}}$ & $\mathrm{Fb}^{\mathrm{b}} \mathrm{p}^{\mathrm{b}}$ & $\begin{array}{c}\text { Mean } \pm \text { SD } \\
(\mathrm{nmol} / \mathrm{L})\end{array}$ & $F^{a} P^{a}$ & $\mathrm{Fb}^{\mathrm{b}} \mathrm{p}^{\mathrm{b}}$ & $\begin{array}{c}\text { Mean } \pm \text { SD } \\
(\mathrm{nmol} / \mathrm{L})\end{array}$ & $F^{a} P^{a}$ & $\mathrm{Fb}^{\mathrm{b}} \mathrm{p}^{\mathrm{b}}$ \\
\hline $\mathrm{C} / \mathrm{C}$ & All & 13 & $104 \pm 43$ & $F=0.76$ & $F=0.22$ & $199 \pm 94$ & $F=1.39$ & $F=0.52$ & $42 \pm 7$ & $F=2.62$ & $F=2.68$ \\
\hline $\mathrm{C} / \mathrm{T}$ & & 52 & $99 \pm 34$ & $p=0.47$ & $p=0.80$ & $176 \pm 68$ & $p=0.25$ & $p=0.59$ & $4 I \pm 7$ & $p=0.08$ & $p=0.07$ \\
\hline $\mathrm{T} / \mathrm{T}$ & & 25 & $96 \pm 41$ & & & $181 \pm 77$ & & & $45 \pm 8$ & & \\
\hline $\mathrm{C} / \mathrm{C}$ & Men & 12 & $104 \pm 44$ & $F=0.99$ & $F=0.98$ & $197 \pm 98$ & $\mathrm{~F}=1.49$ & $F=1.60$ & $43 \pm 7$ & $F=1.93$ & $F=2.06$ \\
\hline $\mathrm{C} / \mathrm{T}$ & & 26 & $91 \pm 35$ & $p=0.38$ & $p=0.38$ & $156 \pm 63$ & $p=0.24$ & $p=0.21$ & $41 \pm 8$ & $p=0.16$ & $p=0.14$ \\
\hline $\mathrm{T} / \mathrm{T}$ & & 14 & $84 \pm 32$ & & & $155 \pm 50$ & & & $46 \pm 8$ & & \\
\hline $\mathrm{C} / \mathrm{C}^{\mathrm{c}}$ & Women & 1 & 107 & $F=0.004$ & $F=0.1 I$ & 229 & $F=0.003$ & $F=0.48$ & 38 & $F=0.78$ & $F=1.23$ \\
\hline $\mathrm{C} / \mathrm{T}^{\mathrm{c}}$ & & 26 & $106 \pm 33$ & $p=0.95$ & $p=0.74^{d}$ & $195 \pm 68$ & $p=0.96$ & $\mathrm{p}=0.49 \mathrm{e}$ & $40 \pm 6$ & $p=0.38$ & $p=0.27^{f}$ \\
\hline$T / T$ & & 11 & $|I| \pm 47$ & & & $214 \pm 93$ & & & $43 \pm 7$ & & \\
\hline
\end{tabular}

5-HIAA = 5-hydroxyindoleacetic acid; HVA = homovanillic acid; MHPG = 3-methoxy-4-hydroxyphenylglycol. Statistical comparisons done on monoamine metabolite residuals corrected ${ }^{a}$ and uncorrected for back length. ${ }^{c} \mathrm{C} / \mathrm{C}$ and $\mathrm{C} / \mathrm{T}$ genotypes were combined in the analyses. ${ }^{d}$ Correction for use of oral contraceptives, $F=0.38, p=0.54$. e Correction for use of oral contraceptives, $F=0.04, p=0.84 .{ }^{f}$ Correction for use of oral contraceptives, $F=1.09, p=0.30$.

Table 4: Dopamine $\beta$-hydroxylase $(D B H)$ genotypes and relationships to monoamine metabolite concentrations in human lumbar cerebrospinal fluid.

\begin{tabular}{|c|c|c|c|c|c|c|c|c|c|c|c|}
\hline \multirow[b]{2}{*}{$\begin{array}{c}\text { DBH } \\
\text { Genotype }\end{array}$} & \multirow[b]{2}{*}{ Sex } & \multirow[b]{2}{*}{$\mathrm{n}$} & \multicolumn{3}{|c|}{ 5-HIAA } & \multicolumn{3}{|c|}{ HVA } & \multicolumn{3}{|c|}{ MHPG } \\
\hline & & & $\begin{array}{c}\text { Mean } \pm \text { SD } \\
(\mathrm{nmol} / \mathrm{L})\end{array}$ & $\mathrm{F}^{\mathrm{a}} \mathrm{P}^{\mathrm{a}}$ & $\mathrm{F}^{\mathrm{b}} \mathrm{p}^{\mathrm{b}}$ & $\begin{array}{c}\text { Mean } \pm \text { SD } \\
(\mathrm{nmol} / \mathrm{L})\end{array}$ & $\mathrm{F}^{\mathrm{a}} \mathrm{P}^{\mathrm{a}}$ & $F^{b} p^{b}$ & $\begin{array}{c}\text { Mean } \pm \text { SD } \\
(\mathrm{nmol} / \mathrm{L})\end{array}$ & $\mathrm{F}^{\mathrm{a}} \mathrm{P}^{\mathrm{a}}$ & $\mathrm{Fb}^{\mathrm{b}} \mathrm{p}^{\mathrm{b}}$ \\
\hline $\mathrm{C} / \mathrm{C}$ & All & 64 & $92 \pm 35$ & $F=9.07$ & $F=6.42$ & $172 \pm 66$ & $F=5.21$ & $F=3.00$ & $42 \pm 7$ & $F=0.01$ & $F=0.01$ \\
\hline $\mathrm{C} / \mathrm{T}^{\mathrm{c}}$ & & 23 & $118 \pm 39$ & $P=0.003$ & $P=0.01$ & $208 \pm 93$ & $P=0.02$ & $P=0.09$ & $42 \pm 9$ & $P=0.90$ & $P=0.93$ \\
\hline $\mathrm{T} / \mathrm{T}^{\mathrm{c}}$ & & 3 & $78 \pm 25$ & & & $151 \pm 18$ & & & $40 \pm 5$ & & \\
\hline $\mathrm{C} / \mathrm{C}$ & Men & 36 & $86 \pm 36$ & $F=4.68$ & $F=3.80$ & $156 \pm 56$ & $F=2.22$ & $F=1.81$ & $43 \pm 7$ & $F=0.08$ & $F=0.04$ \\
\hline $\mathrm{C} / \mathrm{T}^{\mathrm{c}}$ & & 15 & $107 \pm 35$ & $P=0.04$ & $p=0.06$ & $186 \pm 98$ & $p=0.14$ & $p=0.18$ & $43 \pm 10$ & $p=0.78$ & $p=0.84$ \\
\hline $\mathrm{T} / \mathrm{T}^{\mathrm{c}}$ & & I & 95 & & & 160 & & & 45 & & \\
\hline $\mathrm{C} / \mathrm{C}$ & Women & 28 & $101 \pm 31$ & $F=4.08$ & $F=3.37$ & $192 \pm 73$ & $F=3.72$ & $F=1.79$ & $41 \pm 6$ & $F=0.03$ & $F=0.08$ \\
\hline $\mathrm{C} / \mathrm{T}^{\mathrm{c}}$ & & 8 & $139 \pm 38$ & $p=0.05$ & $p=0.07 e$ & $249 \pm 72$ & $P=0.06$ & $P=0.19 d$ & $4 I \pm 7$ & $P=0.87$ & $P=0.78^{f}$ \\
\hline $\mathrm{T} / \mathrm{T}^{\mathrm{c}}$ & & 2 & $70 \pm 30$ & & & $147 \pm 23$ & & & $38 \pm 4$ & & \\
\hline
\end{tabular}

5-HIAA = 5-hydroxyindoleacetic acid; HVA = homovanillic acid; MHPG = 3-methoxy-4-hydroxyphenylglycol. Statistical comparisons done on monoamine metabolite residuals corrected and uncorrected ${ }^{b}$ for back length. ${ }^{\mathrm{c}} \mathrm{T} / \mathrm{T}$ and $\mathrm{C} / \mathrm{T}$ genotypes were combined in the analyses. ${ }^{\mathrm{d}} \mathrm{Correction}$

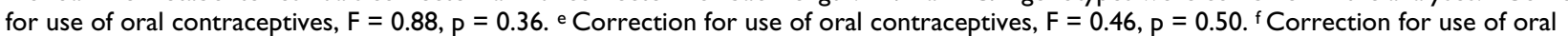
contraceptives, $F=0.003, p=0.96$. Analysing heterosis, i.e. comparing homo- vs heterozygotes: All subjects $5-\mathrm{HIAA}: F=9.56, P=0.003(F=13.07$, $p=0.0005$ after correction for back length). All subjects HVA: $F=4.43, p=0.04(F=7.24, p=0.009)$. Men 5-HIAA: $F=3.85, p=0.06(F=4.6 I 87$, $p=0.04)$. Men HVA: I.95, $p=0.17(F=2.31, p=0.14)$. Women 5 -HIAA: $F=9.14, p=0.005(F=9.74, p=0.004$ and $F=4.11, p=0.05$ corrected for back length and use of oral contraceptives, respectively). Women HVA: $F=4.43, p=0.04(F=6.42, p=0.02$ and $F=1.81, p=0.19$ corrected for back length and use of oral contraceptives, respectively).

smaller male or female sub-samples this difference reached significance (table 4).

We also performed calculations pooling the homozygotic genotypes, i.e. analysing possible heterosis [52]. In the total sample there was an association between $D B H$ heterozygosity and 5-HIAA concentrations $(\mathrm{p}=0.003$ uncorrected, $\mathrm{p}=0.0005$ when corrected for back-length) (table 4). This relationship reached significance also among men ( $p=0.06$ uncorrected, $p=0.04$ corrected for back length) and women ( $\mathrm{p}=0.005$ uncorrected, $\mathrm{p}=0.02$ corrected for back length, $\mathrm{p}=0.05$ corrected for use of oral contraceptives; table 4). In the total sample there was an association ( $\mathrm{p}=0.04$ uncorrected, $\mathrm{p}=0.009$ corrected for back-length) between DBH heterozygosity and HVA concentrations (table 4). This association failed to obtain sig- 
nificance in the smaller male sub-sample. Among women there was an association $(\mathrm{p}=0.04$ uncorrected, $\mathrm{p}=0.02$ corrected for back-length), which however did not survived correction for use of oral contraceptives $(p=0.18$; table 4).

There were no significant relationships between the $D B H$ genotype and MHPG concentrations (table 4).

Given $\alpha=0.05$ the present study had a power of 0.93 0.96 (total sample), $0.67-0.81$ (men), or $0.53-0.67$ (women) to detect differences of a large effect size ( $\mathrm{f}=$ $0.40)$. For differences of a medium effect size $(f=0.25)$ the power was $0.54-0.65$ (total sample) or less.

\section{Discussion}

The present study is, to our knowledge, the first to investigate three potentially functional candidate gene variants (HTR3A $178 \mathrm{C} / \mathrm{T}, \mathrm{DRD} 4-521 \mathrm{C} / \mathrm{T}, \mathrm{DBH}-1021 \mathrm{C} / \mathrm{T}$ ) in the context of monoamine metabolite concentrations in cerebrospinal fluid from human healthy volunteers. Association was detected between two of these gene variants (HTR3A $178 \mathrm{C} / \mathrm{T}, \mathrm{DBH}-1021 \mathrm{C} / \mathrm{T}$ ) and the indirect measures of monoamine activity in the brain.

However, we were not able to replicate the previously reported finding of higher CSF MHPG concentrations in HTR2C Ser23 compared to Cys23 carriers among men [9]. On the contrary, our male sub-sample showed a non-significant relationship in the opposite direction, i.e. higher MHPG concentrations in Cys23 subjects (table 1). When we added another 23 men, excluded from the main analysis because of reported life-time psychiatric disorder, mostly alcohol abuse, depressive or anxiety disorders, this difference reached nominal significance $(\mathrm{F}=4.44$, d.f. $=$ $71, p=0.04)$, a result robust for correction for back-length $(\mathrm{p}=0.04)$ and presence of life-time psychiatric disorder $(\mathrm{p}$ $=0.04$ ), respectively (data not shown). Reasons for the different results in the two studies may include the different selection of subjects. The previous study included $73 \%$ alcoholic violent offenders and $27 \%$ healthy controls of Finnish ethnicity, and the HTR2C genotype effect was most prominent among the offenders [9], whereas the present study only included healthy subjects. The present study may lack power to detect the previous relationship. Alternatively, assuming different relationships between alcoholic violent offenders and healthy controls, the Finnish study may be under-powered concerning control subjects. It is also possible that both results are valid, but the results reflect an association to a linked variant, and that the degree of linkage between the HTR2C Cys23Ser variant and the 'real' functional polymorphism differs between the two populations investigated. There may also be a difference between the two populations with regard to other genes interacting with the present to influence
MHPG concentrations. It is also possible that the Finnish, the present or both results have emerged by chance.

Subjects carrying the rarer HTR3A $178 \mathrm{~T}$ allele, which has been associated with higher protein expression than the wild-type variant [14], displayed higher lumbar CSF 5HIAA concentrations. This suggests that a more efficient variant of the $5-\mathrm{HT}_{3}$ receptor, involved in the regulation of serotonin activities, enhances brain serotonin turnover, giving rise to higher levels of the serotonin degradation product in CSF.

We were not able to find any significant relationships between DRD4 -521 C/T variation and CSF monoamine metabolite concentrations. This is in accordance with previous studies, analysing a DRD4 exon 3 variable number of tandem repeat variant $[42,53]$. In the present report there was a trend for an association between the DRD4 $521 \mathrm{C} / \mathrm{T}$ genotypes and CSF MHPG concentrations. This may mean that the present study does not have sufficient power to detect such a relationship, or that this trend reflects a tendency to a false positive finding. The results so far obtained suggest that the DRD4 gene does not have a large impact on the monoamine turnover in the brain as reflected by the major degradation products of these compounds in healthy human subjects.

One would expect that functional variants of the gene encoding the dopamine $\beta$-hydroxylase would primarily affect the catecholamines, in particular norepinephrine. However, in the present study the strongest relationship emerged between the DBH -1021 C/T variant and CSF 5HIAA levels. Complex interactions between the noradrenergic and serotonergic systems have been reported $[54,55]$. Altered noradrenergic activity may alter the firing activity of serotonergic neurons, leaving a possibility for a decreased or increased availability of norepinehprine to be involved in these interactions. One might speculate that a more effective $D B H$ variant, giving rise to an enhanced norepinephrine formation, facilitates noradrenergic activity, which in its turn facilitates serotonergic activity, giving rise to larger amounts of the serotonin degradation product 5-HIAA. There was also an association between DBH $-1021 \mathrm{C} / \mathrm{T}$ variation and the major dopamine degradation product, indicating higher HVA levels in subjects with a less effective enzyme variant. This is in accordance with the theory that a less effective conversion of dopamine to norepinephrine would lead to higher amounts of dopamine, and in turn to its degradation product HVA. However, the stronger associations between heterozygotic genotypes and 5-HIAA and HVA concentrations, examples of positive heterosis [52], rather indicate a more complex physiology including interactions based on hidden stratification of unknown factors or heterozygotic advantage [52]. In this context, an inter- 
action with e.g. the monoamine oxidase A gene, where more effective variants have been reported to increase 5HIAA concentrations $[43,56]$, may be a possibility. However, these latter results further complicate the task, as they call into question the use of monoamine metabolites as straightforward, although indirect, measures of brain turnover. This may mean that high levels of 5-HIAA may reflect a more effective degradation process rather than an enhanced overall turnover giving a possibility for reduced serotonin transmission to be associated with high levels of 5-HIAA.

It is possible that the present associations may have emerged by chance. Applying Bonferroni's correction would give a p-value of $<0.0011(0.05 / 45)$ to be considered significant. Only one of the reported relationships, i.e. the association between $D B H$ heterozygosity and CSF 5-HIAA levels, would survive such a correction procedure. On the other hand, although relatively large to constitute a sample of healthy subjects investigated by a demanding procedure, i.e. lumbar puncture, the present sample is small from a statistical point of view. The power of the present study was adequate to detect differences of large, but not medium to small effect sizes. Thus, it cannot be excluded that relationships of smaller magnitudes may have escaped our analysis attempts. Applying strict corrections for multiple testing would make investigations like the present impossible to perform, because a sample big enough to withstand such a correction procedure would probably never be possible to obtain. This is especially true taking the detection of small effects into account.

\section{Conclusions}

If replicated, the present results suggests that the HTR3A and $D B H$ variants participate differentially in the regulation of serotonin turnover in the central nervous system of human subjects. It is also suggested that the $D B H$ variant differentially influence dopamine turnover in the brain. The results give some support for an influence of the HTR2C variant on norepinephrine turnover in men, but do not favour a major differential influence of $D R D 4$ gene activities on monoamine metabolite concentrations in lumbar CSF.

\section{Competing interests}

None declared.

\section{Authors' contributions}

EGJ performed the second clinical investigation, the statistical analyses, and drafted the manuscript. JB, JM, RAJ, JS, $\mathrm{LW}$, and RI performed the genotyping. SC, PP, MMN and EE participated in the design and co-ordination of the study. GCS conceived of the study and participated in its design and co-ordination. All authors read and approved the final manuscript.

\section{Acknowledgements}

This study was supported by grants from the Swedish Research Council (8668, K2004-2IX-15078-0IA), Deutsche Forschungsgemeinschaft (SFB400, TPA3), the Fund for Scientific Research - Flanders (G.0425.02), the National Institute for Mental Health (448I4), Söderström-Königska Foundation, the Lundberg Foundation, the Wallenberg Foundation, and the HUBIN project. We thank Kjerstin Lind and Alexandra Tylec for technical assistance.

\section{References}

I. Oxenstierna G, Edman G, Iselius L, Oreland L, Ross SB, Sedvall G: Concentrations of monoamine metabolites in the cerebrospinal fluid of twins and unrelated individuals - a genetic study. J Psychiatr Res 1986, 20:19-29.

2. Higley JD, Thompson WW, Champoux M, Goldman D, Hasert MF, Kraemer GW, Scanlan JM, Suomi SJ, Linnoila M: Paternal and maternal genetic and environmental contributions to cerebrospinal fluid monoamine metabolites in rhesus monkeys (Macaca mulatta). Arch Gen Psychiatry 1993, 50:615-623.

3. Pompeiano M, Palacios JM, Mengod G: Distribution of the serotonin 5-HT2 receptor family mRNAs: comparison between 5HT2A and 5-HT2C receptors. Brain Res Mol Brain Res 1994 , 23:163-178.

4. Blandina P, Goldfarb J, Walcott J, Green JP: Serotonergic modulation of the release of endogenous norepinephrine from rat hypothalamic slices. J Pharmacol Exp Ther 199|, 256:34|-347.

5. Chiang G, Aston-Jones G: A 5-hydroxytryptamine2 agonist augments gamma-aminobutyric acid and amino acid inputs to noradrenergic locus coeruleus neurons. Neuroscience 1993, 54:409-420.

6. Done CJ, Sharp T: Biochemical evidence for the regulation of central noradrenergic activity by 5-HTIA and 5-HT2 receptors: microdialysis studies in the awake and anaesthetized rat. Neuropharmacology 1994, 33:4 I I-42 I.

7. Milatovich A, Hsieh CL, Bonaminio G, Tecott L, Julius D, Francke U: Serotonin receptor Ic gene assigned to $X$ chromosome in human (band q24) and mouse (bands D-F4). Hum Mol Genet 1992, I:68I-684.

8. Lappalainen J, Zhang L, Dean M, Oz M, Ozaki N, Yu DH, Virkkunen $M$, Weight F, Linnoila M, Goldman D: Identification, expression, and pharmacology of a Cys23-Ser23 substitution in the human 5-HT2c receptor gene (HTR2C). Genomics 1995, 27:274-279.

9. Lappalainen J, Long JC, Virkkunen M, Ozaki N, Goldman D, Linnoila M: HTR2C Cys23Ser polymorphism in relation to CSF monoamine metabolite concentrations and DSM-III-R psychiatric diagnoses. Biol Psychiatry 1999, 46:82I-826.

10. Miyake A, Mochizuki S, Takemoto Y, Akuzawa S: Molecular cloning of human 5-hydroxytryptamine3 receptor: heterogeneity in distribution and functionamong species. Mol Pharmacol 1995, 48:407-4I6

II. Matsumoto M, Yoshioka M, Togashi H, Tochihara M, lkeda T, Saito $\mathrm{H}$ : Modulation of norepinephrine release by serotonergic receptors in the rat hippocampus as measured by in vivo microdialysis. J Pharmacol Exp Ther 1995, 272: 1044-105I.

12. Benloucif S, Keegan MJ, Galloway MP: Serotonin-facilitated dopamine release in vivo: pharmacological characterization. J Pharmacol Exp Ther 1993, 265:373-377.

13. Tricklebank MD: The functional importance of 5-HT3 receptors in the interactions between serotonergic and dopaminergic systems in the CNS. In Central and Peripheral 5-HT3 receptors Edited by: Hamen M. London: Academic Press; 1992: 189-205.

14. Niesler B, Flohr T, Nöthen MM, Fischer C, Rietschel M, Franzek E, Albus M, Propping P, Rappold GA: Association between the 5' UTR variant C178T of the serotonin receptor gene HTR3A and bipolar affective disorder. Pharmacogenetics 200I, I I:47I - 475

15. Melke J, Westberg L, Nilsson S, Landén M, Soderstrom H, Baghaei F, Rosmond R, Holm G, Björntorp P, Nilsson LG, Adolfsson R, Eriksson $E: A$ polymorphism in the serotonin receptor $3 A$ gene (HTR3A) is associated with harm avoidance in women. Arch Gen Psychiatry 2003, 60:1017-1023.

16. Lahti RA, Roberts RC, Conley RR, Cochrane EV, Mutin A, Tamminga $C A$ : D2-type dopamine receptors in postmortem human 
brain sections from normal and schizophrenic subjects. Neuroreport 1996, 7:1945-1948.

17. Rubinstein M, Phillips TJ, Bunzow JR, Falzone TL, Dziewczapolski G, Zhang G, Fang Y, Larson JL, McDougall JA, Chester JA, Saez C, Pugsley TA, Gershanik O, Low MJ, Grandy DK: Mice lacking dopamine D4 receptors are supersensitive to ethanol, cocaine, and methamphetamine. Cell 1997, 90:99I-I00I.

18. Tarazi Fl, Baldessarini RJ: Brain dopamine $D(4)$ receptors: basic and clinical status. Int J Neuropsychopharmcol 1999, 2:41-58.

19. Gelernter J, Kennedy JL, Van Tol HHM, Civelli O, Kidd KK: The D4 dopamine receptor (DRD4) maps to distal IIp close to HRAS. Genomics 1992, 13:208-210.

20. Okuyama $\mathrm{Y}$, Ishiguro $\mathrm{H}$, Toru $\mathrm{M}$, Arinami $\mathrm{T}$ : A genetic polymorphism in the promoter region of DRD4 associated with expression and schizophrenia. Biochem Biophys Res Commun 1999 , 258:292-295.

21. Okuyama $Y$, Ishiguro $H$, Nankai M, Shibuya $H$, Watanabe A, Arinami $\mathrm{T}$ : Identification of a polymorphism in the promoter region of DRD4 associated with the human novelty seeking personality trait. Mol Psychiatry 2000, 5:64-69.

22. Ronai Z, Szekely A, Nemoda Z, Lakatos K, Gervai J, Staub M, SasvariSzekely M: Association between Novelty Seeking and the -52I C/Tpolymorphism in the promoter region of the DRD4 gene. Mol Psychiatry 200I, 6:35-38.

23. Bookman EB, Taylor RE, Adams-Campbell L, Kittles RA: DRD4 promoter SNPs and gender effects on Extraversion in African Americans. Mol Psychiatry 2002, 7:786-789.

24. Lee HJ, Lee HS, Kim YK, Kim SH, Kim L, Lee MS, Joe SH, Jung IK, Suh $\mathrm{KY}$, Kim S: Allelic variants interaction of dopamine receptor D4 polymorphism correlate with personality traits in young Korean female population. Am J Med Genet 2003, I I 8B:76-80

25. Mitsuyasu H, Hirata N, Sakai $Y$, Shibata H, Takeda K, Ninomiya H, Kawasaki $H$, Tashiro N, Fukumaki Y: Association analysis of polymorphisms in the upstream region of the human dopamine D4 receptor gene (DRD4) with schizophrenia and personality traits. J Hum Genet 200I, 46:26-3I.

26. Jönsson EG, Ivo R, Forslund K, Mattila-Evenden M, Rylander G Cichon S, Propping P, Nöthen MM, Åsberg M, Sedvall GC: No association between a promoter dopamine D4 receptor gene variant and schizophrenia. Am J Med Genet 200I, 105:525-528.

27. Jönsson EG, Ivo R, Gustavsson JP, Geijer T, Forslund K, MattilaEvenden M, Rylander G, Cichon S, Propping P, Bergman H, Åsberg M, Nöthen MM: No association between dopamine D4 receptor gene variants and Novelty Seeking. Mol Psychiatry 2002, 7:18-20.

28. Ekelund J, Suhonen J Järvelin MR, Peltonen L, Lichtermann D: No association of the $-52 \mathrm{I} \mathrm{C/T}$ polymorphism in the promoter of DRD4 with novelty seeking. Mol Psychiatry 200I, 6:618-619.

29. Strobel A, Lesch KP, Hohenberger K, Jatzke S, Gutzeit HO, Anacker $K$, Brocke $B$ : No association between dopamine $D 4$ receptor gene exon III and-52IC/T polymorphism and Novelty Seeking. Mol Psychiatry 2002, 7:537-538.

30. Strobel A, Spinath FM, Angleitner A, Riemann R, Lesch KP: Lack of association between polymorphisms of the dopamine D4 receptor gene and personality. Neuropsychobiology 2003, 47:52-56.

31. Joyce PR, Rogers GR, Miller AL, Mulder RT, Luty SE, Kennedy MA Polymorphisms of DRD4 and DRD3 and risk of avoidant and obsessive personality traits and disorders. Psychiatry Res 2003 I I9:I-10.

32. Schinka JA, Letsch EA, Crawford FC: DRD4 and novelty seeking: results of meta-analyses. Am J Med Genet 2002, I | 4:643-648.

33. Munafò MR, Clark TG, Moore LR, Payne E, Walton R, Flint J: Genetic polymorphisms and personality in healthy adults: a systematic review and meta-analysis. Mol Psychiatry 2003, 8:47I-484.

34. Jönsson EG, Sedvall GC, Nöthen MM, Cichon S: Dopamine D4 receptor gene (DRD4) variants and schizophrenia: metaanalyses. Schizophr Res 2003, 61: III-II9.

35. Kemper CM, O'Connor DT, Westlund KN: Immunocytochemical localization of dopamine-beta-hydroxylase in neurons of the human brain stem. Neuroscience 1987, 23:98I-989.

36. Oka K, Kijikawa K, Ohuchi T, Yoshida H, Imaizumi R: Distribution of dopamine- $\beta$-hydroxylase activity in subcellular fractions of adrenal medulla. Life Sci 1967, 6:46 I-465.

37. Weinshilboum RM: Biochemical genetics of catecholamines in humans. Mayo Clin Proc 1983, 58:319-330.
38. Craig SP, Buckle VJ, Lamouroux A, Mallet J, Craig IW: Localization of the human dopamine beta hydroxylase (DBH) gene to chromosome 9q34. Cytogenet Cell Genet 1988, 48:48-50.

39. Zabetian CP, Anderson GM, Buxbaum SG, Elston RC, Ichinose $H$ Nagatsu T, Kim KS, Kim CH, Malison RT, Gelernter J, Cubells JF: A quantitative-trait analysis of human plasma-dopamine betahydroxylase activity: Evidence for a major functional polymorphism at the DBH locus. Am J Hum Genet 200I, 68:5I5-522.

40. Köhnke MD, Zabetian CP, Anderson GM, Kolb W, Gaertner I, Buchkremer G, Vonthein R, Schick S, Lutz U, Köhnke AM, Cubells JF: A genotype-controlled analysis of plasma dopamine betahydroxylase in healthy and alcoholic subjects: evidence for alcohol-related differences in noradrenergic function. Biol Psychiatry 2002, 52:1151-II58.

4I. Zabetian CP, Buxbaum SG, Elston RC, Köhnke MD, Anderson GM, Gelernter J, Cubells JF: The structure of linkage disequilibrium at the DBH locus strongly influences the magnitude of association between diallelic markers and plasma dopamine beta-hydroxylase activity. Am J Hum Genet 2003, 72: I 389- 1400.

42. Jönsson E, Sedvall G, Brené S, Gustavsson JP, Geijer T, Terenius L, Crocq M-A, Lannfelt L, Tylec A, Sokoloff P, Schwartz JC, Wiesel F-A: Dopamine-related genes and their relationships to monoamine metabolites in CSF. Biol Psychiatry 1996, 40:1032-1043.

43. Jönsson EG, Norton N, Gustavsson JP, Oreland L, Owen MJ, Sedvall GC: A promoter polymorphism in the monoamine oxidase $A$ gene and its relationships to monoamine metabolite concentrations in CSF of healthy volunteers. J Psychiatr Res 2000, 34:239-244.

44. American Psychiatric Association: Diagnostic and Statistical Manual of Mental Disorders Thirdth edition. Washington DC: American Psychiatric Association; 1987.

45. Sedvall G, Fyrö B, Gullberg B, Nybäck H, Wiesel F-A, Wode-Helgodt $B$ : Relationships in healthy volunteers between concentrations of monoamine metabolites in cerebrospinal fluid and family history of psychiatric morbidity. $\mathrm{Br} J$ Psychiatry 1980 , 136:366-374.

46. Swahn C-G, Sandgärde B, Wiesel F-A, Sedvall G: Simultaneous determination of the three major monoamine metabolites in brain tissue and body fluids by a mass fragmentographic method. Psychopharmacology 1976, 48: 147-I52.

47. Geijer T, Neiman J, Rydberg U, Gyllander A, Jönsson E, Sedvall G, Valverius $\mathrm{P}$, Terenius L: Dopamine D2 receptor gene polymorphisms in Scandinavian chronic alcoholics. Eur Arch Psychiatry Clin Neurosci 1994, 244:26-32.

48. Jönsson EG, Abou Jamra R, Schumacher J, Flyckt L, Edman G, Forslund K, Mattila-Evenden M, Rylander G, Åsberg M, Bjerkenstedt L, Wiesel F-A, Propping P, Cichon S, Nöthen MM, Sedvall GC: No association between a putative functional promoter variant in the dopamine $\beta$-hydroxylase gene and schizophrenia. Psychiatr Genet 2003, 13:175-178.

49. Jönsson EG, Goldman D, Spurlock G, Gustavsson JP, Nielsen DA, Linnoila M, Owen MJ, Sedvall GC: Tryptophan hydroxylase and catechol-O-methyltransferase gene polymorphisms. Relationships to monoamine metabolite concentrations in CSF of healthy volunteers. Eur Arch Psychiatry Clin Neurosci 1997, 247:297-302

50. Cohen J: Statistical power analysis for the behavioral sciences. Hillsdale, New Jersey: Lawrence Erlbaum Associates; 1988.

5I. Erdfelder E, Faul F, Buchner A: GPower: a general power analysis program. Behav Res Methods Instruments Comput 1996, 28: I-I I.

52. Comings DE, MacMurray JP: Molecular heterosis: a review. Mol Genet Metab 2000, 71: 19-31.

53. Adamson MD, Kennedy J, Petronis A, Dean M, Virkkunen M, Linnoila M, Goldman D: DRD4 dopamine receptor genotype and CSF monoamine metabolites in Finnish alcoholics and controls. Am J Med Genet 1995, 60:199-205.

54. Svensson TH: Brain noradrenaline and the mechanisms of action of antidepressant drugs. Acta Psychiatr Scand Volume 402. Suppl.; 2000:18-27.

55. Blier P: Crosstalk between the norepinephrine and serotonin systems and its role in the antidepressant response. J Psychiatry Neurosci 200I, 26:S3-SIO.

56. Williams RB, Marchuk DA, Gadde KM, Barefoot JC, Grichnik K, Helms MJ, Kuhn CM, Lewis JG, Schanberg SM, Stafford-Smith M, Suarez EC, Clary GL, Svenson IK, Siegler IC: Serotonin-related gene 
polymorphisms and central nervous system serotonin function. Neuropsychopharmacology 2003, 28:533-54I.

\section{Pre-publication history}

The pre-publication history for this paper can be accessed here:

http://www.biomedcentral.com/1471-244X/4/4/prepub

Publish with Biomed Central and every scientist can read your work free of charge

"BioMed Central will be the most significant development for disseminating the results of biomedical research in our lifetime. " Sir Paul Nurse, Cancer Research UK

Your research papers will be:

- available free of charge to the entire biomedical community

- peer reviewed and published immediately upon acceptance

- cited in PubMed and archived on PubMed Central

- yours - you keep the copyright 